\title{
PHD Defence: "The Bombing of Air India Flight 182: Demanding Justice, Public Inquiries, and Acts of Citizenship" by Milan Singh
}

\author{
Sibo Chen \\ School of Communication \\ Simon Fraser University \\ Our dear colleague, Milan Singh, successfully defended her PHD dissertation on July 30, 2015. Here \\ is the abstract of her dissertation "The Bombing of Air India Flight 182: Demanding Justice, Public \\ Inquiries, and Acts of Citizenship".
}

\begin{abstract}
On June 23, 1985 Air India Flight 182 exploded over the Irish sea, killing all 329 people onboard the aircraft. The attack was planned and executed on Canadian soil, and the majority of passengers were Canadian citizens. Canadian authorities failed to effectively investigate the bombing, and provide families of the victims with adequate support for the traumatic losses they underwent (Air India Inquiry Report, 2010). This is despite families' repeatedly demanding the Canadian government for information, services, and a thorough criminal investigation into the bombings. Many families claimed the government treated them like "second-rate" citizens and questioned whether systemic racism was a factor in how the criminal investigation was handled (for example see Public Hearings, 2006, p.47).

Like other racialized Canadians in the 1980s, families of Air India Flight 182 victims mobilized to demand justice. Arguing that the bombings were a "Canadian issue" they pressured the government to call a public inquiry. In 2005, the Canadian government announced the Official Commission of Inquiry into the Investigation of the Bombing of Air India Flight 182, which was mandated to examine the failures of the criminal investigation and provide recommendations to prevent future acts of terrorism in Canada. In 2006, the Air India Inquiry began with public hearings where victims' families gave testimonies that were meant to help understand the "human element" of the tragedy. Families' testimonies were transcribed into fourteen volumes with over 1,000 pages that detailed their grief, the impact of the bombing on their lives, the negligent treatment by the Canadian government and their political struggles for recognition over twenty years.

This thesis examines families' testimonies and triangulates their statements with media reports and excerpts from the federal Hansard debates to (a) reconstruct the steps they took to demand justice, and (b) examine the way they used discourses of citizenship to demonstrate how their government failed them. Using families' testimonies as evidence, this thesis challenges conventional definitions of multicultural citizenship, arguing that discourses of citizenship need to consider the agency of subjects and the challenges they face when they demand justice. This thesis draws on the concept of "acts of citizenship" (Isin, 2009; 2012) to show that citizenship needs to be understood through the actions subjects take in their pursuit of justice. In Communication Studies, this thesis offers a new approach to examining public inquiries (Salter, 2007) and the construction of identity in relation to racialization (Hall, 1990; Jiwani, 2006) by drawing on the scholarship of Bannerji (2000), Dhamoon (2009), Isin (2012), Miki (2004) and Nyers (2004) who argue that current models of citizenship are rooted in relations of exclusion.
\end{abstract}

\section{Keywords}

The bombing of Air India Flight 182; public inquiry; acts of citizenship; racialization; Cultural Studies; mobilizing for justice; "culture of redress" 